\title{
Proteomics viewed on stress response of thermophilic bacterium Bacillus stearothermophilus TLS33
}

\author{
Supachai Topanurak1,2, Supachok Sinchaikul', Suree Phutrakul', Boonyaras Sookkheo ${ }^{3}$ \\ and Shui-Tein Chen ${ }^{1,4}$ \\ ${ }^{1}$ Institute of Biological Chemistry and Genomics, Academia Sinica, Taipei, Taiwan \\ 2 Department of Chemistry, Faculty of Science, Chiang Mai University, Chiang Mai, Thailand \\ ${ }^{3}$ Department of Chemistry, Faculty of Science, Rangsit University, Pathunthani, Thailand \\ ${ }^{4}$ Institute of Biochemical Sciences, College of Life Science, National Taiwan University, Taiwan
}

Thermophilic bacterium Bacillus stearothermophilus TLS33, isolated from a hot spring in Chiang Mai, Thailand, usually produces many enzymes that are very useful for industrial applications. However, the functional properties and mechanisms of this bacterium under stress conditions are rarely reported and still need more understanding on how the bacterium can survive in stress environments. In this study, we examined the oxidative stress induced proteins of this bacterium by proteomic approach combining two-dimensional electrophoresis and mass spectrometry. When the bacterium encountered oxidative stress, peroxiredoxin, as an antioxidant enzyme, is one of the interesting stressed proteins which appeared to be systematically increased with different $\mathrm{p} I$. There are four isoforms of peroxiredoxin, denoted as Prx I, Prx II, Prx III and Prx IV, which are observed at the same molecular weight of $27 \mathrm{kDa}$ but differ in $\mathrm{p} I$ values of 5.0, 4.87, 4.81 and 4.79, respectively. The $\mathrm{H}_{2} \mathrm{O}_{2}$ concentration directly increased Prx II, Prx III and Prx IV intensities, but decreased Prx I intensity. These shifting of peroxiredoxin isoforms may occur by a post-translational modification. Otherwise, the longer time of oxidative stress had not affected the expression level of peroxiredoxin isoforms. Therefore, this finding of peroxiredoxin intends to know the bacterial adaptation under oxidative stress. Otherwise, this protein plays an important role in many physiological processes and able to use in the industrial applications.

\section{Keywords:}

Bacillus stearothermophilus / Peroxiredoxin / Stress / Thermophile
Received: June 6, 2004 Revised: December 27, 2004 Accepted: January 17, 2005

\section{Introduction}

Thermophile organisms grow optimally at temperatures above $60-70^{\circ} \mathrm{C}$. Since thermophiles have several unique physiological and metabolic characteristics, they are very usefully exploited in the biotechnological industry for wide applications [1-3]. They also include biotransformations, biocatalysis, bioremediation or bioactive compound production, for example, whereby whole thermophile cell or puri-

Correspondence: Professor Dr. Shui-Tein Chem, Institute of Biological Chemistry (RM707), Academia Sinica, 128 Yen Chiu Yuan Rd., Sec. II, Nankang, Taipei, 11529, Taiwan

E-mail: bcchen@gate.sinica.edu.tw

Fax: +886-2-27883473 fied thermostable enzymes. Biocatalytic reactions by microorganisms are also found to be chemoselective, regioselective and stereoselective, therefore allowing production of optically active compounds as well [4]. These abilities are used in the pharmaceutical and agrochemical industries for the biocatalysts of non-natural products. However, thermophiles are often exposed to multiple environmental stresses during bioprocessing; for example, low and high temperatures, low and high $\mathrm{pH}$ values, high osmotic pressure, nutrient starvation and oxidation. Among these stress factors, oxidation can be considered one of the most deleterious to the cell, causing cellular damage at both molecular and metabolic levels [5]. In addition, the reactive oxygen species (ROS) derived from the reduction of dioxygen itself is less reactive and from the reduction of dioxygen to superoxide $\left(\mathrm{O}_{2}^{-}\right)$, hydrogen per- 
oxide $\left(\mathrm{H}_{2} \mathrm{O}_{2}\right)$ or the hydroxyl radical $\left(\mathrm{OH}^{\prime}\right)$ are highly reactive and able to efficiently damage nucleic acids, membrane lipids and proteins [6]. To eliminate the excess ROS, many organisms use peroxiredoxin system to scavenge the excess ROS which can be harmful to cells [7-15]. Peroxiredoxins (Prx) or alkyl hydroperoxide reductase cysteines (AhpC) are enzymes in a family of thiol-specific peroxides which are found in plants and some microorganisms [16-21]. They are implicated in a wide variety of cellular processes including proliferation [22], differentiation [23], and the immune response [24] as well as in the detoxification of peroxides. They represent a special case which constitutes both the peroxidase and the cosubstrate because the enzyme itself is oxidized upon reaction with the peroxide. Peroxiredoxins have cysteines at their active site which can be oxidized by the peroxide and forms to be cysteine sulphinic acid. Although there have been some reports describing the function of peroxiredoxin [25-27], the changes of their isoforms have never been studied in this bacterium.

At present, proteomic techniques using two-dimensional electrophoresis (2-DE) and mass spectrometry are the credible approaches which are widely used to study the alteration of protein expression in organisms under different environmental conditions and further more understanding of the biology of whole organism cells [28-32]. Thermophilic bacterium Bacillus stearothermophilus TLS33, isolated from a natural hot spring in Chiang Mai, Thailand, is an interesting thermophile that usually grow well in a hot environment at $65^{\circ} \mathrm{C}$ and produce many thermostable enzymes, such as proteases [33], lipase [34] and superoxide dismutase [35], that are very useful for industrial applications. According to its thermostability and applications, it is challenging to investigate the intracellular proteome of thermophilic bacterium B. stearothermophilus TLS33 under oxidative stress which is one of the general stresses resulting from extreme conditions from industrial bioprocessing. Using a proteomic approach, we found that peroxiredoxin is the interesting protein which is firstly observed a major difference of the protein expression in this bacterium, responding to oxidative stress. Furthermore, there are four isoforms of peroxiredoxin with the identical molecular weight but different in $\mathrm{pI}$. Then, we examined the leveled change of the peroxiredoxin isoforms which may play an important role in a protective mechanism under oxidative stress and able to be used in the bioprocessing and other industrial applications.

\section{Materials and methods}

\subsection{Bacterial culture and stress experiment}

B. stearothermophilus TLS33, isolated from a soil in a hot spring in Chiang Mai, Thailand, was picked a colony from an agar plate and inoculated into $50 \mathrm{~mL}$ of nutrient broth (ADSA Micro, Barcelona, Spain) in $250 \mathrm{~mL}$ flask as preculture. The preculture was incubated in the water bath at $65^{\circ} \mathrm{C}$ with shaking at $200 \mathrm{rpm}$. After $24 \mathrm{~h}$ of precultivation, $1 \mathrm{~mL}$ of cell suspension was transferred to $100 \mathrm{~mL}$ of fresh nutrient broth in $250 \mathrm{~mL}$ flask (triplicate for each experiment). The bacterium was cultured at $65^{\circ} \mathrm{C}$ until mid-log phase $\left(\mathrm{OD}_{600} \sim 0.6\right)$ and subsequently added the hydrogen peroxide (Riedel de Haën, Seelze, Germany) into the media with the final concentration of 10, 50, 100 and $500 \mu \mathrm{M}$ in each flask. After half hour interval of $\mathrm{H}_{2} \mathrm{O}_{2}$ induction, the bacterial cells were observed at $600 \mathrm{~nm}$ and harvested by centrifugation at $4^{\circ} \mathrm{C}, 8500 \mathrm{rpm}$ for $10 \mathrm{~min}$. The survival percentage is defined that the $\mathrm{OD}_{600}$ at starting induction of $\mathrm{H}_{2} \mathrm{O}_{2}$ is set as $100 \%$. The bacterial cells were washed three times with preparation buffer pH 8.0 containing $10 \mathrm{~mm}$ Tris- $\mathrm{HCl}$, $1 \mathrm{~mm}$ EDTA and $0.1 \mathrm{~mm}$ PMSF.

\subsection{Sample preparation}

The bacterial cells were disrupted by sonication with $4 \mathrm{~s}$ pulse for $10 \mathrm{~min}$ in preparation buffer $\mathrm{pH} 8.0$ containing $10 \mathrm{~mm}$ Tris-HCl, $1 \mathrm{~mm}$ EDTA and $0.1 \mathrm{~mm}$ PMSF, and the supernatant was obtained by centrifugation at $4^{\circ} \mathrm{C}$, $12000 \mathrm{rpm}$ for $20 \mathrm{~min}$. The sample solutions were precipitated by addition of $10 \%$ TCA and $0.1 \% \mathrm{w} / \mathrm{v}$ DTT. The mixture was stored overnight at $-20^{\circ} \mathrm{C}$ and the pellet was obtained by centrifugation at $10000 \times \mathrm{g}, 4^{\circ} \mathrm{C}$ for $15 \mathrm{~min}$. The pellet was washed twice, first with cold acetone containing $20 \mathrm{~mm}$ DTE and secondly with cold acetone without DTT, and centrifuged as described above. The supernatant was removed and the pellet was vacuum dried.

\subsection{Two-dimensional electrophoresis (2-DE)}

Lyophilized protein samples were resolved in lysis buffer containing $7 \mathrm{~m}$ urea, $2 \mathrm{~m}$ thiourea, 4\% CHAPS, 4 mM TCEP, $100 \mathrm{~mm}$ DTE and $0.5 \%$ IPG buffer $\mathrm{pH} 4-7 \mathrm{~L}$. The protein sample solutions containing $100 \mu \mathrm{g}$ protein concentration in $350 \mu \mathrm{L}$ total volume were applied on IPGphor strip (Amersham Biosciences, $18 \mathrm{~cm}, 4-7 \mathrm{~L}$ ) using IPGphor (Amersham Biosciences, Uppsala, Sweden).

The first-dimensional isoelectric focusing (IEF) on IPGphor was performed under the following condition: $30 \mathrm{~V}$, 12 h (rehydration); 100 V, 3 h; 350 V, 1 h; 500 V, 1 h; $1000 \mathrm{~V}$, $1 \mathrm{~h} ; 5000 \mathrm{~V}, 1 \mathrm{~h} ; 8000 \mathrm{~V}, 55 \mathrm{kVh}$. After IEF, the IPG strips were equilibrated in equilibration buffer I (50 mM Tris- $\mathrm{HCl}$ $\mathrm{pH} 8.8,6 \mathrm{~m}$ urea, 30\% v/v glycerol, $2 \% \mathrm{w} / \mathrm{v}$ SDS, $2 \% \mathrm{w} / \mathrm{v}$ DTE and a trace of bromophenol blue) for $15 \mathrm{~min}$, and then subsequently alkylated in buffer II (50 mM Tris- $\mathrm{HCl} \mathrm{pH} 8.8$, $6 \mathrm{M}$, urea, $30 \% \mathrm{v} / \mathrm{v}$ glycerol, $2 \% \mathrm{w} / \mathrm{v}$ SDS, $2.5 \% \mathrm{w} / \mathrm{v}$ iodoacetamide and a trace of bromophenol blue) for $15 \mathrm{~min}$. Each equilibrated IPG strip was placed on top of the $15 \%$ homogenous polyacrylamide gel $(185 \times 200 \times 1.5 \mathrm{~mm})$ and covered with $0.5 \%$ agarose. The second-dimensional separation using PROTEAN II xi Multi-Cells (Bio-Rad) was carried out at $45 \mathrm{~mA}$ per gel at $15^{\circ} \mathrm{C}$ until the bromophenol blue dye front reached the bottom of the gel. At the end of each run, the 2-D gels were stained with $\mathrm{SYPRO}^{\circledR}$ Ruby [36] and 
scanned using a Typhoon 9200 scanncer (Amersham Biosciences). In addition, the 2-D gel images were exported to the image analysis software program, using ImageMaster ${ }^{\mathrm{TM}} 2 \mathrm{D}$ platinum software (Amersham Biosciences) which provides the 3-D viewing and the protein intensity of each spot.

\subsection{In-gel digestion}

Protein spots were manually excised from the gels and transferred to $500 \mu \mathrm{L}$ siliconized Eppendorfs. The gel pieces were washed twice with $200 \mu \mathrm{L}$ of $50 \%$ ACN/25 mM ammonium bicarbonate buffer, $\mathrm{pH}$ 8.0, for $15 \mathrm{~min}$ each. The gel pieces were then washed once with $200 \mu \mathrm{L}$ of $100 \%$ ACN and dried using a Speed Vac concentrator. Dried gel pieces were swollen in $10 \mu \mathrm{L}$ of $25 \mathrm{~mm}$ ammonium bicarbonate containing $0.1 \mu \mathrm{g}$ trypsin (Promega, Madison WI, USA). Gel pieces were then crushed with siliconized blue stick and incubated at $37^{\circ} \mathrm{C}$ for at least $16 \mathrm{~h}$. Peptides were subsequently extracted twice with $50 \mu \mathrm{L}$ of $50 \% \mathrm{ACN} / 5 \% \mathrm{TFA}$, then the extracted solutions were combined and dried using a SpeedVac concentrator. The peptides or pellets were then resuspended in $10 \mu \mathrm{L}$ of $0.1 \%$ TFA and the suspended solutions were purified using ZipTip C18 (Millipore, Billerica, MA, USA). Ten microliters of sample were drawn up and down in the ZipTip 10 times and the ZipTip was washed with $10 \mu \mathrm{L}$ of $0.1 \%$ formic acid by drawing up and expelling the washing solution for three times. The peptides were eluted with $5 \mu \mathrm{L}$ of $75 \%$ ACN $/ 0.1 \%$ formic acid.

\subsection{Protein identification by MALDI-TOF MS/MS}

This method was performed as described by Lee et al. [37]. Briefly, MALDI-TOF MS/MS were performed on a dedicated Q-Tof Ultima ${ }^{\mathrm{TM}}$ MALDI instrument (Micromass) with fully automated data directed acquisition using predefined probe motion pattern and peak intensity threshold for switching over from MS survey scan to MS/MS, and from one MS/MS to another. At a laser firing rate of $10 \mathrm{~Hz}$, individual spectra from $5 \mathrm{~s}$ integration period acquired for each of the MS/MS performed were combined, smoothed, deisotoped (fast option) and centroided using the Micromass PGS 2.0 data processing software. All individual MS/MS data thus generated from a particular sample well were then output as a single MASCOT-searchable peak list file and all peak list files generated from each the 1-D $\mu \mathrm{LC}$ fractions as deposited by Probot $^{\text {TM }}$ on the corresponding MALDI sample well were manually combined into a single .pkl file before searching against the NCBIr database using MASCOT program.

\subsection{Protein modification analysis by LC-ESI nanoMS/MS}

The tryptic digested peptides from each Prx isoform were analyzed by 1-D LC-nanoESI MS/MS. The 1-D LC-nanoESIMS/MS analysis was performed on an integrated nanoLCMS/MS system (Mircomass) comprising a three-pumping
Micromass/Waters CapLC ${ }^{\mathrm{TM}}$ system with an autosampler, a stream select module configured for precolumn plus analytical capillary column, and a Micromass Q-Tof Ultima ${ }^{\text {TM }}$ API mass spectrometer fitted with nano-LC sprayer, operated under MassLynx ${ }^{\mathrm{TM}} 4.0$ control. Injected samples were first trapped and desalted isocratically on an LCPackings PepMap ${ }^{\text {TM }}$ C18 $\mu$-Precolumn ${ }^{\text {TM }}$ Cartidge $(5 \mu \mathrm{m}$, $300 \mu \mathrm{m}$ id $\times 5 \mathrm{~mm}$; Dionex, Sunnyvale, CA, USA) for $2 \mathrm{~min}$ with $0.1 \%$ formic acid delivered by the auxillary pump at $30 \mu \mathrm{L} / \mathrm{min}$ after which the peptides were eluted off from the precolumn and separated on an analytical C18 capillary column $(15 \mathrm{~cm} \times 75 \mu \mathrm{m}$ id, packed with $5 \mu \mathrm{m}$, Zorbax 300 SB C18 paticles; Micro-Tech Scientific, Vista, CA, USA) connected inline to the mass spectrometer, at $300 \mathrm{~nL} / \mathrm{min}$ using a $40 \mathrm{~min}$ fast gradient of $5 \%$ to $80 \%$ acetonitrile in $0.1 \%$ formic acid.

\section{Results and discussion}

\subsection{Bacterial survival of $B$. stearothermophilus TLS33 under oxidative stress}

The survival of thermophile B. stearothermophilus TLS33 after treatment with different concentrations of $\mathrm{H}_{2} \mathrm{O}_{2}$ is shown in Fig. 1. In general, hydrogen peroxide $\left(\mathrm{H}_{2} \mathrm{O}_{2}\right)$ produced the reactive oxygen species (ROS) which are generated aerobically by auto-oxidation of electron transport chain components and, when present in excess, can damage various components of living cells [7-15]. Thus, the percentage of bacterial survival decreased after addition of $\mathrm{H}_{2} \mathrm{O}_{2}$ from 50 to $500 \mu \mathrm{M}$, except $10 \mu \mathrm{M} \mathrm{H} \mathrm{H}_{2} \mathrm{O}_{2}$. Although all concentrations of $\mathrm{H}_{2} \mathrm{O}_{2}$ were not shown to be highly affected to the bacterial cells along 120 min of stressed time with the survival higher than $85 \%$, the increase of $\mathrm{H}_{2} \mathrm{O}_{2}$ concentration effectively decreased the survival of this bacterium.

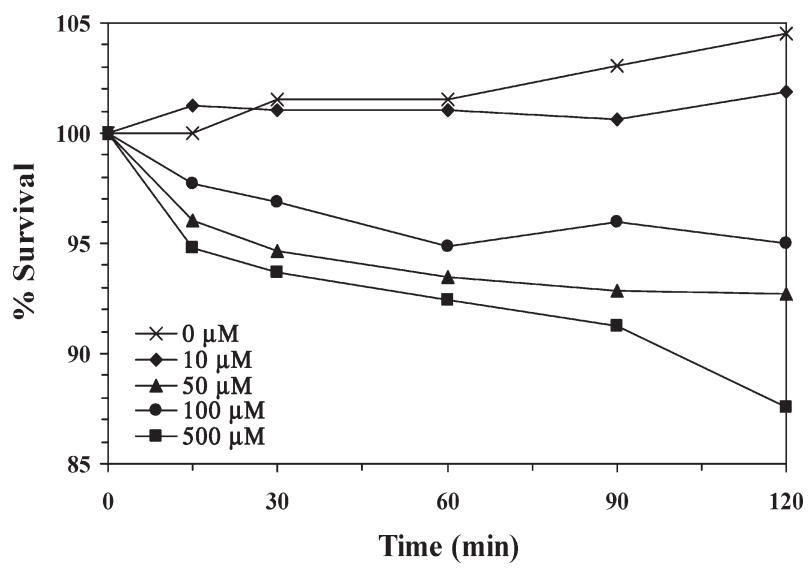

Figure 1. Survival percentage of $B$. stearothermophilus TLS33 after addition of different concentrations of $\mathrm{H}_{2} \mathrm{O}_{2}(10,50,100$ and $500 \mu \mathrm{M}$ ) for $120 \mathrm{~min}$. 


\subsection{2-DE analysis of B. stearothermophilus TLS33 cells}

Although the regulation in gene level of bacteria under oxidative stress has been reported, the regulation in protein level including protein expression and post-translational modification are rarely studied in this bacterium. In order to better understand the stress response of B. stearothermophilus TLS33 under oxidative condition, we used the proteomic approach to detect and identify proteins that are differentially expressed in bacterial cell that is resistant to oxidative stress within a short period time of $15 \mathrm{~min}$. After addition of different concentrations of $\mathrm{H}_{2} \mathrm{O}_{2}, 2-\mathrm{DE}$ analysis of the intracellular proteins of B. stearothermophilus TLS33 demonstrated a few changes in the protein patterns (Fig. 2). Interestingly, four isoform spots at the low molecular weight approximately $27 \mathrm{kDa}$ were markedly changed. Subsequently, the protein digests of three isoform spots were analyzed by MALDI-TOF MS/MS and identified to be the same protein called peroxiredoxin (Prx) and denoted as Prx I, Prx II, Prx III and Prx IV. Moreover, the probability-based scoring of the mass spectrums of peroxiredoxin isoforms derived from the calculation by Perkins et al. [38] informed the high scoring of mass database search which indicated that these four spots were peroxiredoxin reliably (Table 1 ). In addition, those isoforms Prx I, Prx II, Prx III and Prx IV appeared at the same molecular weight but different in $\mathrm{p} I$ with 5.0, 4.87, 4.81 and 4.79 , respectively. We suggest that a shift to a more acidic spot position may be caused by post-translational modification which might occur in response to oxidative stress when cysteine residues are oxidized to sulphinic acid [39-42].

In general, peroxiredoxins are a ubiquitous family of antioxidant enzymes, which play an important role in many physiopathological processes, including adaptation to oxygen $[43,44]$. It is well known that peroxiredoxins control cytokine-induced peroxide levels which mediate signal transduction in mammalian cells. They can be regulated by changes to phosphorylation, redox and possibly oligomerization states [45, 46]. They are also significantly elevated in human thyroid tumors [47] and in the area of brain that are most susceptible to hypoxic and ischemic injury [48]. Recently, the interesting study of peroxiredoxin by genomebased bioinformatics selection showed its function as a vaccine candidate for anthrax disease [49]. In the case of bacteria, the metabolic context of peroxiredoxins and its physiological relevance have not yet been widely studied, especially the alteration of peroxiredoxin isoform depending on the oxidative state. In our results, we first found that thermophile B. stearothermophilus TLS33 produced the peroxiredoxins with four isoforms when encountering oxidative stress. In fact, two isoforms of peroxiredoxins I and II (Prx I and II) normally appeared in the cytosol of this bacterium. After addition of $\mathrm{H}_{2} \mathrm{O}_{2}$ and incubation for $15 \mathrm{~min}$, the peroxiredoxin isoforms were shifted depending on the $\mathrm{H}_{2} \mathrm{O}_{2}$ concentration. This evidence can be supported by the previous study which reported that the acidic form of peroxiredoxins was an oxidative modified form after organisms have encountered oxidative stress, whereas the basic form was the normal form of peroxiredoxins [41]. We suggest that the reactive oxygen species (ROS) can oxidize the peroxiredoxins and modify it to become four isoforms when the bacterium encountered oxidative stress. Thus, we could observe the increase of Prx II, Prx III and Prx IV in the oxidative stress condition.

\subsection{Expression of peroxiredoxin isoforms}

Since peroxides are weak oxidizing agents, they can react with cysteinyl-thiols in proteins by formation of disulfide bonds or sulphinic acid derivatives [50]. While cells are growing, significant amounts of $\mathrm{O}_{2}{ }^{-}$and $\mathrm{H}_{2} \mathrm{O}_{2}$ are generated by enzymatic misdirection of electrons to dioxygen. It is assumed that flavin-dependent transfer reactions of respiratory chain are primarily responsible for generation of ROS. If

Table 1. Protein identification of four isoforms of peroxiredoxin from thermophile Bacillus stearothermophilus TLS33

\begin{tabular}{|c|c|c|c|c|c|c|}
\hline Isoform & $\begin{array}{l}\text { Mass } \\
(\mathrm{kDa})\end{array}$ & $\mathrm{p} /$ & $\begin{array}{l}\text { MOWSE } \\
\text { score }\end{array}$ & $\begin{array}{l}\text { Peptide } \\
\text { matched } \\
\text { no }\end{array}$ & $\begin{array}{l}\text { Sequence } \\
\text { coverage } \\
(\%)\end{array}$ & Matching sequence \\
\hline $\operatorname{PrxI}$ & 27 & 5.00 & $347^{\text {a) }}$ & 4 & 38 & MFDVLDEEQGLAQR \\
\hline Prx II & 27 & 4.87 & $252^{\text {a) }}$ & 4 & 27 & IEYVMIGDPSHOLSR \\
\hline Prx III & 27 & 4.81 & $80^{\text {a) }}$ & 4 & 7 & $\begin{array}{l}\text { AQAYHNGEFIEVTEQDFMGK } \\
\text { GTFIIDPDGVIQAVEINADGIGR }\end{array}$ \\
\hline Prx IV & 27 & 4.78 & $131^{\text {a) }}$ & 3 & 27 & $\begin{array}{l}\text { MFDVLDEEQGLAQR } \\
\text { IEYVMIGDPSHOLSR } \\
\text { GTFIIDPDGVIQAVEINADGIGR }\end{array}$ \\
\hline
\end{tabular}

a) The score indicates identity or extensive homology. (Protein scores are derived from MASCOT software.) 

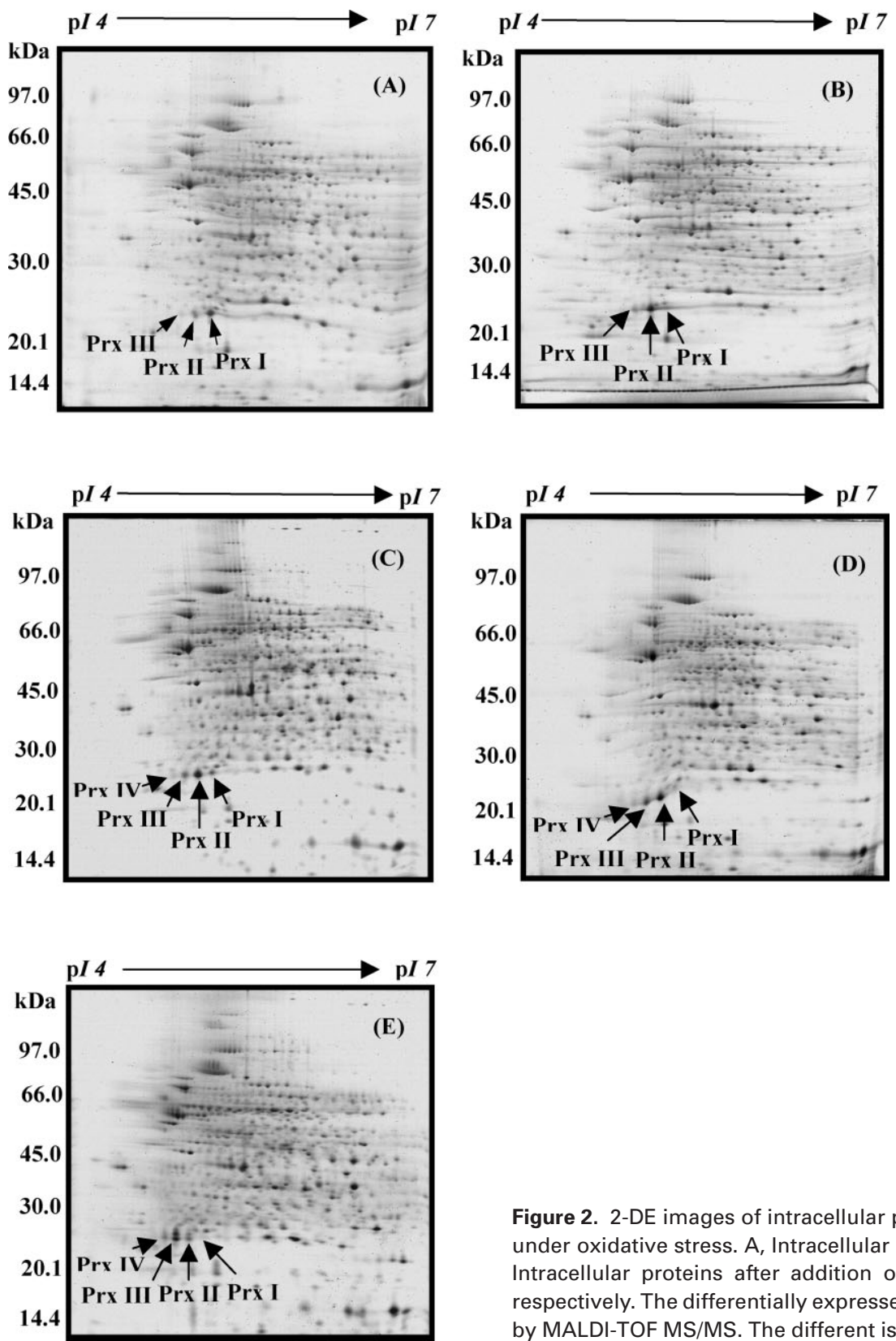

Figure 2. 2-DE images of intracellular proteome of Bacillus stearothermophilus TLS33 under oxidative stress. A, Intracellular proteins under control condition; B, C, D and E, Intracellular proteins after addition of $10,50,100$ and $500 \mu \mathrm{m}$ of $\mathrm{H}_{2} \mathrm{O}_{2}$ for $15 \mathrm{~min}$, respectively. The differentially expressed proteins under oxidative stress were analyzed by MALDI-TOF MS/MS. The different isoforms of peroxiredoxin are shown by arrows.

the amount of ROS increases to toxic levels, cells encounter oxidative stress. In this study, we used $\mathrm{H}_{2} \mathrm{O}_{2}$ as an oxidative stressor to investigate how bacterial cells protect themselves from harmful conditions of oxidative stress. By the results, peroxiredoxin is one interesting protein which showed a significant difference in protein expression level. In order to conveniently visualize the peroxiredoxin isoform appearance, 3-D viewings of peroxiredoxin area under different concentrations of $\mathrm{H}_{2} \mathrm{O}_{2}$ were generated by using ImageMaster $^{\mathrm{TM}}$ 2D platinum software and used to examine alterations of peroxiredoxin (Fig. 3A). In addition, the volume of peak area in 3-D viewing of peroxiredoxin isoforms can be equivalent to the protein intensity as shown in Fig. 3B. The image viewings showed Prx I normally located on the basic region while Prx II, Prx III and Prx IV located on the acidic region. In the presence of different $\mathrm{H}_{2} \mathrm{O}_{2}$ concentrations, 2-D and 3-D viewings demonstrated the markedly different expression level of peroxiredoxin isoforms, which are dependent on the concentration of $\mathrm{H}_{2} \mathrm{O}_{2}$, especially at the high concentration of $500 \mu \mathrm{M}$. Interestingly, Prx III slightly appeared in the absence of $\mathrm{H}_{2} \mathrm{O}_{2}$ and in the low concentration of $10 \mu \mathrm{M} \mathrm{H} \mathrm{H}_{2} \mathrm{O}_{2}$ whereas Prx IV was not observed. The appearance of Prx III and Prx IV occurred in the presence of $50 \mu \mathrm{M} \mathrm{H} \mathrm{H}_{2} \mathrm{O}_{2}$ condition and/or higher concentration of $\mathrm{H}_{2} \mathrm{O}_{2}$. 
(A)
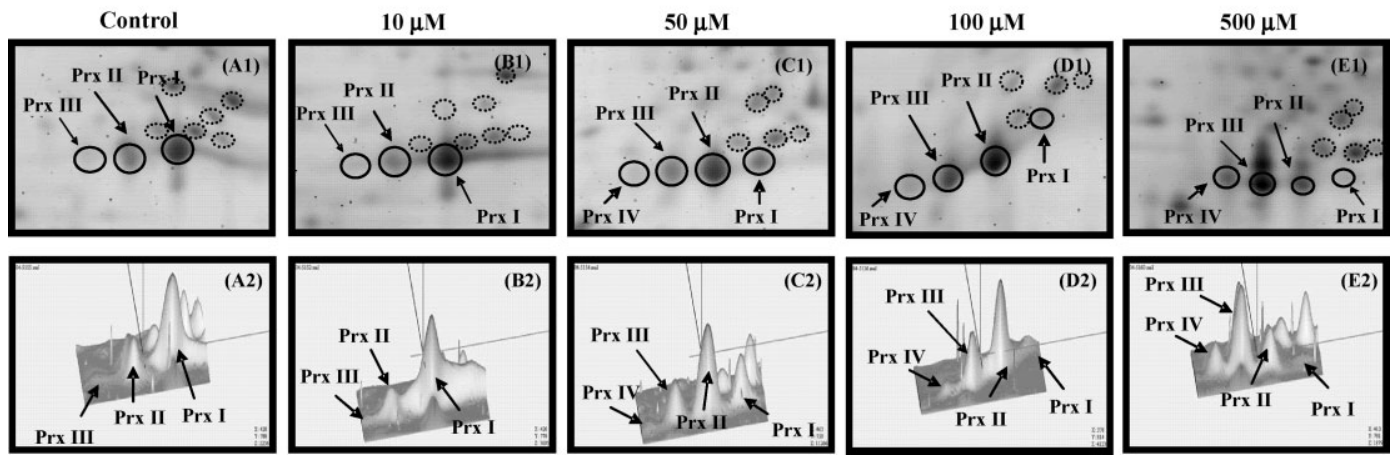

(B)

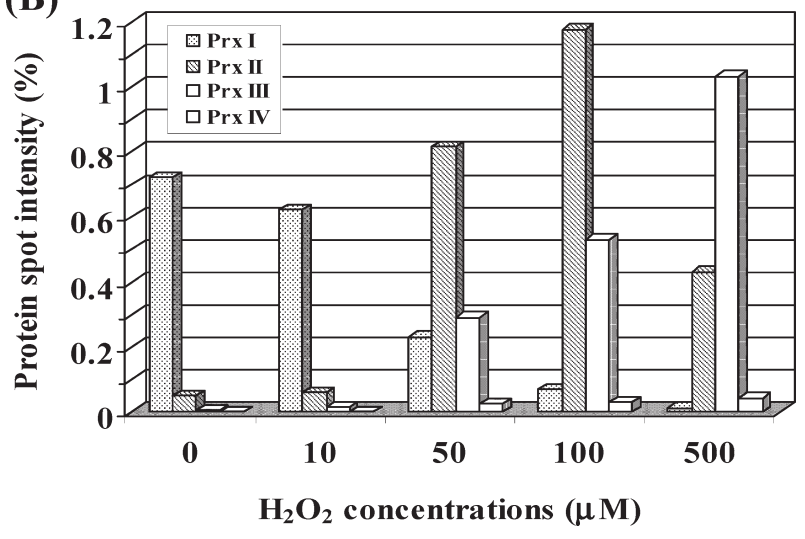

Figure 3. Representative of peroxiredoxin expression in $B$. stearothermophilus TLS33 under oxidative stress by addition of different concentrations of $\mathrm{H}_{2} \mathrm{O}_{2}$. (A), 2-D and 3-D images covering the peroxiredoxin isoform region under different concentrations of $\mathrm{H}_{2} \mathrm{O}_{2}$ for $15 \mathrm{~min}$. The volume of peak area represents the intensities of protein spots. $A$, control (no addition of $\left.\mathrm{H}_{2} \mathrm{O}_{2}\right) ; \mathrm{B}, 10 \mu \mathrm{M} \mathrm{H}_{2} \mathrm{O}_{2} ; \mathrm{C}, 50 \mu \mathrm{M} \mathrm{H}_{2} \mathrm{O}_{2} ; \mathrm{D}, 100 \mu \mathrm{M} \mathrm{H} \mathrm{H}_{2} ; \mathrm{E}, 500 \mu \mathrm{m}$ $\mathrm{H}_{2} \mathrm{O}_{2}$. (B), Percentage of protein spot intensity of peroxiredoxin isoforms on different $\mathrm{H}_{2} \mathrm{O}_{2}$ concentrations. These percent spot volumes were generated by ImageMaster ${ }^{\text {TM }} 2 \mathrm{D}$ platinum.

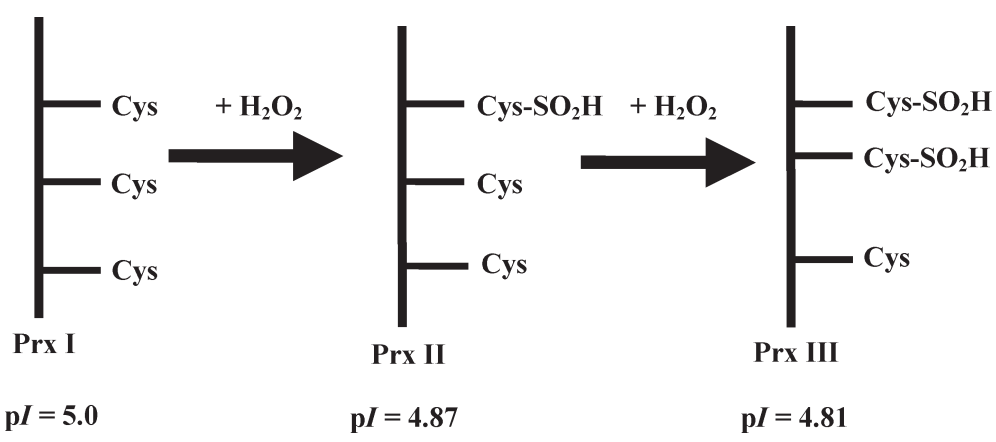

Figure 4. Hypothesis of B. stearothermophilus TLS33 peroxiredoxin isoforms that are modified by $\mathrm{H}_{2} \mathrm{O}_{2}$. The modification of active site cysteines resulted in acidic shift of peroxiredoxin by forming the complex with sulphinic acid at active site residue.

In the absence of $\mathrm{H}_{2} \mathrm{O}_{2}$, Prx I showed the highest intensity rather than Prx II, Prx III and Prx IV, respectively. When the concentration of $\mathrm{H}_{2} \mathrm{O}_{2}$ was increased, the Prx I intensity was decreased whereas Prx II, Prx III and Prx IV intensities were increased (Fig. 3B). Thus, we conclude that the intensities of Prx II, Prx III and Prx IV are directly increased to the concentration of $\mathrm{H}_{2} \mathrm{O}_{2}$ and the appearance of peroxiredoxin isoforms are regulated by $\mathrm{H}_{2} \mathrm{O}_{2}$. Otherwise, these evidences may be post-translational modification which has also been reported and that the acidic spot was confirmed to be a modified form because the active-site cysteines were oxidized and turned into cysteine sulphinic acid [42, 50, 51]. Thus, we presume that the modified cysteines with sulphinic acids in the protein molecule may formulate the proteins to have positive charge and intend to shift the $\mathrm{pI}$ of the protein. Therefore, the level of oxidative stress directly affected the modification of peroxiredoxin isoforms and the active-site cysteines may be modified by $\mathrm{H}_{2} \mathrm{O}_{2}$ to be obtain the acidic form (Fig. 4).

\subsection{Post-translational modification by LC-MS/MS analysis}

According to our presumption, the Prx isoforms would be modified with ROS or $\mathrm{H}_{2} \mathrm{O}_{2}$ and formed sulphinic acid in cysteine residues $\left(\mathrm{Cys}-\mathrm{SO}_{2} \mathrm{H}\right)$. To characterize the modifica- 
tions taking place in the acid spots, both the normal and acidic spots from Prx were analyzed by LC-MS/MS. A modified peptide was found at the LC-MS stage as a peak occurring only in the acidic spots of Prx II and Prx III and not in the basic one of Prx I (Fig. 5). There were $598 \mathrm{~m} / z$ peaks in Prx II, and $598 \mathrm{~m} / z$ and $809 \mathrm{~m} / z$ peaks in Prx III, in which these peaks are different from its native form (Prx I). To confirm the hypothesis, these tryptic digestion peptides were analyzed by collision-induced dissociation. From MS/MS spectrum in Fig. 5, it indicates the $\mathrm{H}_{2} \mathrm{O}_{2}$ oxidized $\mathrm{SH}$ group in cysteine residue of both Prx II and Prx III. A mass difference of 135 absolute mass units was detected between the b3 and b4 ion in $598 \mathrm{~m} / z$ peak of both of Prx II and III and between b6 and b7 in $809 \mathrm{~m} / z$ peak of Prx III, indicative of the presence of a cysteinyl residue modified by two oxygen atoms. According to our purpose the $\mathrm{H}_{2} \mathrm{O}_{2}$ would oxidize disulfide group in another cysteine residue in Prx II and cause the protein to shift to a more acidic region which formed Prx III, herein this was proved by the presence of $598 \mathrm{~m} / z$ and $809 \mathrm{~m} / z$ peak in Prx III but it was found that only $598 \mathrm{~m} / z$ is present in Prx II. However, due to the high sequence conservation between Prx II and III, we speculate that the acidic Prx III spot also corresponds to an oxidized form at the active site. This has also been reported in the similar modification [42]. For Prx IV, we could not find the mass difference of 135 mass units. However, we will investigate the fourth isoform in a further study.

\subsection{Effect of stressed time on modification of peroxiredoxin isoforms under oxidative stress}

According to the results of different concentration of $\mathrm{H}_{2} \mathrm{O}_{2}$, Prx II showed the highest intensity at $100 \mu \mathrm{M}$ of $\mathrm{H}_{2} \mathrm{O}_{2}$ and subsequently decreased at $500 \mu \mathrm{M}$, while Prx III and Prx IV were directly variable to the increase of $\mathrm{H}_{2} \mathrm{O}_{2}$ concentrations. Hence, we examined the effect of stressed time on the irreversible oxidation of peroxiredoxin isoforms by adding the high concentration of $500 \mu \mathrm{M} \mathrm{H}_{2} \mathrm{O}_{2}$. At $120 \mathrm{~min}$ of stress period, Prx I showed the decreased intensity whereas Prx III showed the increased intensity (Fig. 6). Surprisingly, peroxiredoxin isoform called Prx IV eventually appeared in the rather acidic region ( $\mathrm{pI}$ 4.79) when the stressed time was longer. The longer stressed time period had no affect on the reversible oxidation of peroxiredoxin isoforms to return to its original form. This finding indicated that when the bacterium encountered higher oxidative stress, the oxidized forms of Prx III and Prx IV were not altered themselves to any reduced forms. According to the previous reports, the oxidation of the active site cysteine to the sulphinic state has also been considered to be irreversible [52-54]. Otherwise, the reversibility of Prx III to its original form (Prx I) is probably difficult because of the stability of sulphinic acid $\left(\mathrm{RSO}_{2} \mathrm{H}\right)$ which was obtained from modification of cysteine residue. Nevertheless, it is necessary to further study that whether $\mathrm{H}_{2} \mathrm{O}_{2}$ is not presented in all oxidized surrounding conditions of bacterial cells, these proteins would be reduced and re-
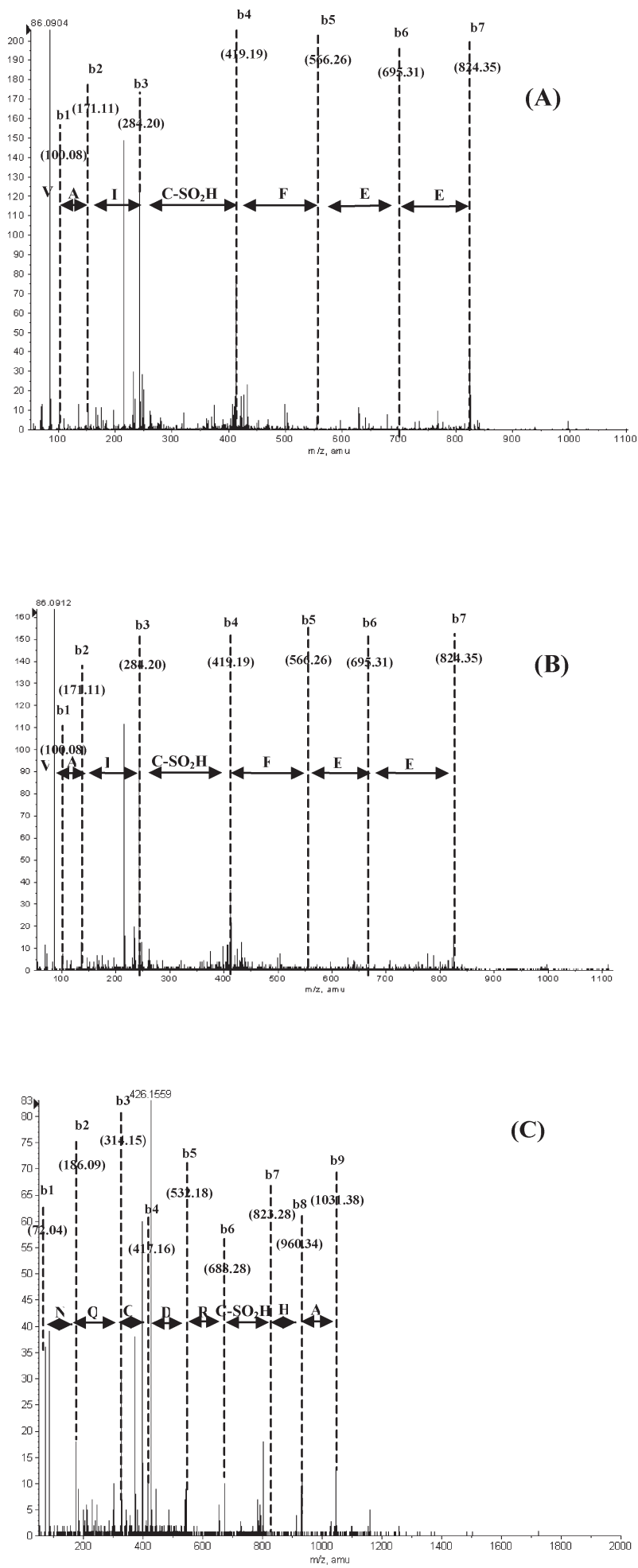

Figure 5. Collision-induced dissociation spectrum of the Prx II $598 \mathrm{~m} / \mathrm{z}$ peak (A) and Prx III - $598 \mathrm{~m} / \mathrm{z}$ peak (B) and $809 \mathrm{~m} / \mathrm{z}$ peak $(C)$. The $m / z$ ion peaks are shown on the top of peak. The amino acid sequences were calculated from the difference of mass units of $b$ ion series. The difference of mass units of 135 was derived from the calculation of cysteine molecular weight (103) plus two oxygen atoms (32). 

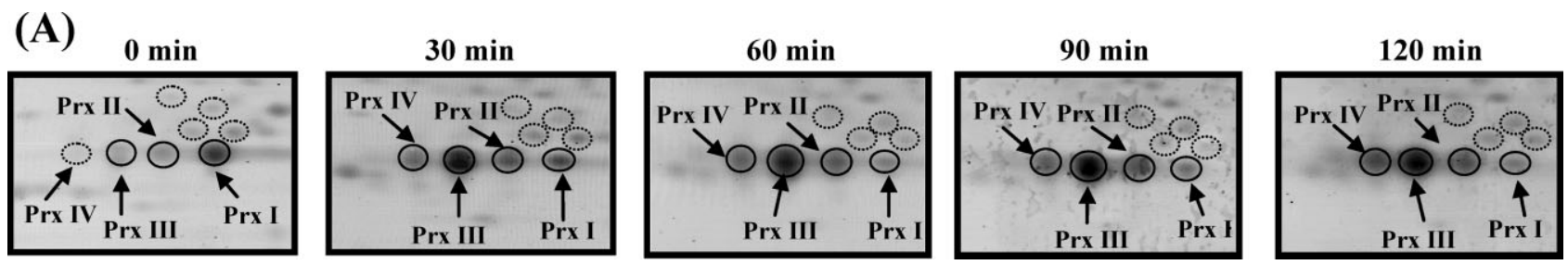

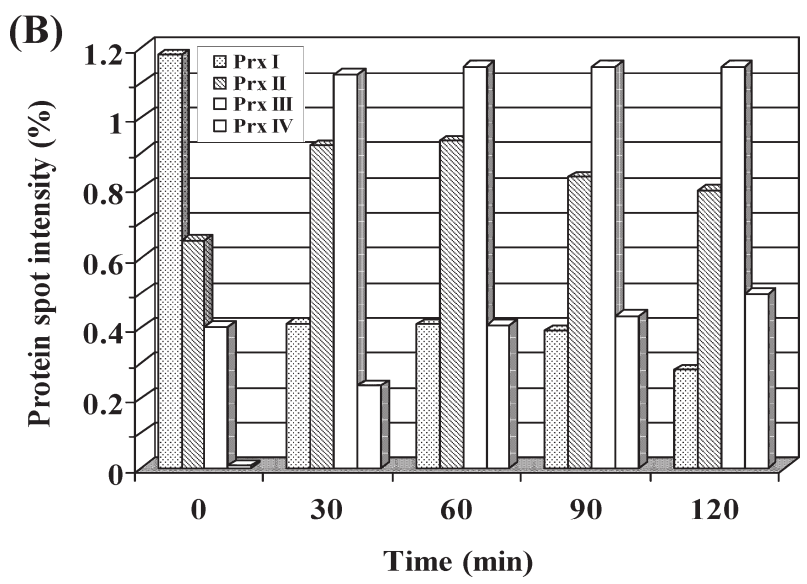

turned to its original form. For this reason, the regulatory pathway of these proteins and other proteins under oxidative stress will be further studied.

\section{Concluding remarks}

In summary, this study is the first finding of peroxiredoxin in the thermophilic bacterium B. stearothermophilus TLS33 that produced many isoforms to reduce ROS when it encountered oxidative stress. By proteomic approach combining 2-DE and mass spectrometry, we detected an alteration of the peroxiredoxin isoforms upon oxidative stress, showing the increased intensity of acidic form of peroxiredoxin. Analysis of tryptic peptides generated from the peroxiredoxin spots in the basic and acidic areas by mass spectrometry provided the different isoforms of peroxiredoxin that had the same molecular weight but different $\mathrm{pI}$. This modification by $\mathrm{pI}$ shifting may be caused by adding a negative charge to form a complex with the protein and shifting the $\mathrm{p} I$ to be more acid. This evidence is possible to use this protein as diagnostic indicators or protein markers in physiological condition or use in the industrial applications.

This report is part of Royal Golden Jubilee Ph.D. project of Mr. Supachai Topanurak supported by the Thailand Research Fund (TRF), Thailand. We gratefully acknowledge the support of the National Research Program for Genomic Medicine of National Science Council, Taiwan (NSC 91-3112-13-001-002) and the support of Academia Sinica, Taiwan for a grant of the Bacillus research. We also thank the core facilities for proteomic
Figure 6. Representative of peroxiredoxin expression in B. stearothermophilus TLS33 under oxidative stress in different stressed times. (A), 2-DE images of peroxiredoxin isoforms in the presence of $500 \mu \mathrm{M} \mathrm{H}_{2} \mathrm{O}_{2}$ and different time points. Note that the isoforms were not changed through the bacterium encountered oxidative stress along the incubation times. (B), Percentage of protein spot intensity of peroxiredoxin isoforms on different times after addition of $500 \mu \mathrm{M} \mathrm{H}_{2} \mathrm{O}_{2}$. These percent spot volumes were generated by ImageMaster ${ }^{\mathrm{TM}} 2 \mathrm{D}$ platinum.

research, Academia Sinica, Taiwan for proteomics facilities, and the Graduated School, Chiang Mai University, Chiang Mai, Thailand, for supporting this work. Finally, we appreciatedly thank Dr. Hsueh-Fen Juan, Department of Life Science, Institute of Molecular and Cellular Biology, National Taiwan University, Taipei, Taiwan, for supporting of MALDI-TOF-MS/MS and the suggestions to us.

\section{References}

[1] Schallmey, M. Singh, A. Ward, O. P. Can. J. Microbiol. 2004, 50, 1-17.

[2] Sinchaikul, S., Sookkheo, B., Topanuruk, S., Juan, H. F., Phutrakul, S., Chen, S. T., J. Chromatogr. B 2002, 771, 261287.

[3] Demirjian, D. C., Morís-Varas, F., Cassidy, C. S., Curr. Opin. Chem. Biol. 2001, 5, 144-151.

[4] Bustard, M. T., Burgess, J. G., Meeyoo V., Wright, P. C., J. Chem. Tech. Biotech. 2000, 75, 1095-1109.

[5] Miyoshi, A., Rochat, T., Gratadoux, J. J., Loir, L. L., Costa, O., Langella, P., Azevedo, V., Genet. Mol. Res. 2003, 2, 348-349.

[6] Mostertz, J., Scharf, C., Hecker, M., Homuth, G., Microbiology 2004, 150, 497-512.

[7] Fratelli, M., Demol, H., Puype, M., Casagrande, S., Villa, P., Eberini, I., Vadekerckhove, J., Gianazza, E., Ghezzi, P., Proteomics 2003, 3, 1154-1161.

[8] Kim, D. M., Swartz, J. R., Biotech. Bioeng. 2004, 2, 123-129.

[9] Klichko, V., Radyuk, S. N., Orr, W. C., Arch. Insect Biochem. Physio. 2004, 56, 34-50.

[10] Gromer, S., Urig, S., Becker, K., Med. Res. Rev. 2004, 24, 40 89. 
[11] Sarafian, T. A., Verity, M. A., Vinters, H. V., Shih, C. Y., Shi, L., Xiang, D. J., Dong, L., Shau, H., J. Neurosci. Res. 1999, 56, 206-212.

[12] Evrard, C., Capron, A., Marchand, C., Clippe, A., Waittiez, R., Soumillion, P., Knoops, B., Declercq, J. P., J. Mol. Biol. 2004, $337,1079-1090$.

[13] Isermann, K., Liebau, E., Roeder, T., Bruchhaus, I., J. Mol. Biol. 2004, 338, 745-755.

[14] Budanov, A. V., Sabina, A. A., Feinstein, E., Koonin, E., Chumakov, P. M., Science 2004, 304, 597-560.

[15] Li, H., Singh, A. K., Mcityre, L. M., Sherman, L. A., J. Bacteriol. 2004, 186, 3331-3345.

[16] Dietz, K. J., Annu. Rev. Plant Biol. 2003, 54, 93-107.

[17] Horling, F., Lamkemeyer, P., Konig, J., Finkemeier, I., Kandlbinder, A., Baier, M., Diestz, K. J., Plant Phys. 2003, 131, 317325.

[18] Nishimaya, Y., Massey, V., Takeda, K., Kawasaki, S., Sato, J., Watanabe, T., Nuumura, Y., J. Bacteriol. 2001, 183, 24312438.

[19] Logan, C., Mayhew, S., J. Biol. Chem. 2000, 275, 3001930028.

[20] Wilkinson, S. R., Temperton, N. J., Mondragon, A., Kelly, J., J. Biol. Chem. 2000, 275, 8220-8225.

[21] Antelmann, H., Engelmann, S., Schmid, R., Hecker, M., J. Bacteriol. 1996, 178, 6571-6578.

[22] Prosperi, M. T., Ferbus, D., Karczinshi, I., Goubin, G., J. Biol. Chem. 1993, 268, 11050-11056.

[23] Nemato, Y., Yamamoto, T., Takada, S., Matsui, Y., Obinata, M., Gene 1990, 91, 261-265.

[24] Shau, H., Butterfield, L. H., Chiu, R., Kim, A., Immunogenetics 1994, 40, 129-134.

[25] Konig, J., Baier, M., Horling, F., Kahmann, U., Harris, G., Schurmann, P., Dietz, K. J., Proc. Natl. Acad. Sci. USA 2002, 99, 5738-5743.

[26] Dietz, K. J., Horing, F., Konig, J., Baier, M., J. Exp. Bot. 2002, $53,1321-1329$.

[27] Prouzet-Mauleou, V., Monribot-Espagne, C., Boucherie, H., Lagniel, G., Lopez, S., Labrre J., Garin, J., Lauquin, G. J. M., J. Biol. Chem. 2002, 277, 4823-4830.

[28] Eymann, C., Dreisbach, A., Albrecht, D., Bernhardt, J., Becher, D., Gentner, S., Tam, L. T., Büttner, K., Buurman, G., Scharf, C., Venz, S., Völker, U., Hecker, M., Proteomics 2004, 4, 2849-2876.

[29] Voigt, B., Schweder, T., Becher, D., Ehrenreich, A., Gottschalk, G., Feesche, J., Maurer, K. H., Hecker, M., Proteomics 2004, 4, 1465-1490.

[30] Bernhardt, J., Volker, U., Volker, A., Antelmann, H., Schmid, R., Mach, H., Hecker, M., Microbiology 1997, 143, 999-1017.

[31] Gohar, M., økstad, O. A., Gilois, N., Sanchis, V., Kolst, A. B., Lereclus, D., Proteomics 2002, 2, 784-791.

[32] Büttner, K., Bernhardt, J., Scharf, C., Schmid, R., Mäder, U., Eymann, C., Antelmann, H., Volker, A., Volker, U., Hecker, M., Electrophoresis 2001, 22, 2908-2935.
[33] Sinchaikul, S., Sookkheo, B., Phutrakul, S., Pan, F. M., Chen, S. T., Protein Expres. Purif. 2001, 22, 388-398.

[34] Sookkheo, B., Sinchaikul, S., Phutrakul, S., Chen, S. T., Protein Expres. Purif. 2000, 20, 142-151.

[35] Sookkheo, B., Sinchaikul, S., Thannan, H., Thongprasong, O., Phutrakul, S., Chen, S. T., Proteomics 2002, 2, 1311-1315.

[36] Berggren, K., Chernokalskaya, E., Steinberg, T. H., Kemper, C., Lopez, M. F., Diwu, Z., Haugland, R. P., Patton, W. F., Electrophoresis 2000, 21, 2509-2521.

[37] Lee, C. L., Hsiao, H. H., Lin, C. W., Wu, S. P., Huang, S. Y., Wu, C. Y., Wang, A. H. J., Khoo, K. H., Proteomics, 2003, 3, 2472 2486.

[38] Perkins, D. N., Pappin, D. J. C., Crasy, D. M., Cottrell, J. S., Electrophoresis 1999, 20, 3551-3567.

[39] Weber, H., Engelmann, S., Becher, D., Hecker, M., Mol. Microbiol. 2004, 52, 133-140.

[40] Yang, K. S., Kang, S. W., Woo, H. A., Hwang, S. C., Chae, H. Z., Kim, K., Rhee, S. G., J. Biol. Chem. 2002, 277, 3802928036.

[41] Wagner, E., Luche, S., Penna, L., Chevallet, M., Dorsselaser, A. V., Leize-Wagner, L., Rabilloud, T., Biochem. J. 2002, 366, 777-785.

[42] Rabilloud, T., Heller, M., Gasneir, F., Luche, S., Rey, C., Aebersold, R., Benahmed, M., Louisot, P., Lunardi, J., J. Biol. Chem. 2002, 22, 19396-19401.

[43] Sayed, A. A., William, D. L., J. Biol. Chem. 2004, in press.

[44] Chae, H. Z., Robison, K., Poole, L. B., Church, G., Storz, G., Rhee, S. G., Proc. Natl. Acad. Sci. USA 1994, 91, 7017-7021.

[45] Hofmann, B., Hecht, H. J., Flohe, L., Biol. Chem. 2002, 383, 347-364

[46] Wood, Z. A., Schroder, E., Harris, J. R., Poole, L. B., Trends Biochem. Sci. 2003, 28, 32-40.

[47] Yanagawa, T., Ishikawa, T., Ishii, T., Tabuchi, K., Iwasa, S., Bannai, S., Omura, K., Suzuki, H., Yoshida, H., Cancer Lett. 1999, 145, 127-132.

[48] Ichimiya, S., Davis, J. G., O'Rourke, D. M., Katsumata, M., Greene, M. I., DNA Cell Biol. 1997, 16, 311-321.

[49] Ariel, N., Zvi, A., Makarova, K. S., Chitlaru, T., Elhanany, E., Velen, B., Cohen, S., Friedlander, A. M., Shaffermann, A., Infect. Immun. 2003, 71, 4563-4579.

[50] Cabiscol, E., Tamarit, J., Ros, J., Int. Microbiol. 2000, 3, 3-8.

[51] Wood, Z. A., Poole, L. B., Karplus, A., Science 2003, 300, 650653.

[52] Woo, H.A., Chae, H.Z., Hwang, S. C., Yang, K. S., Kang, S. W., Kim, K., Rhee, S. G., Science 2003, 300, 656-653.

[53] Claiborne, A., Yeh, J. I., Mallett, T. C., Luba, J., Crane, E. J., Charrier, V., Parsonge, D., Biochemistry 1999, 38, 1540715416.

[54] Schroder, E., Littlechild, J. A., Lebedev, A. A., Errington, N., Vagin, A. A., Isonpv, M. N., Struct. Fold Des. 2000, 8, 605-615. 